\title{
Uncontrolled and under-diagnosed asthma in a Damascus shelter during the Syrian crisis
}

\author{
Yousser Mohammad ${ }^{1,2}$, Shaaban Rafea ${ }^{1,2}$, Youssef Latifeh $^{2,3}$, Ali Khaddam ${ }^{2,4}$, Bisher Sawaf ${ }^{2}$, Mhd Ismael \\ Zakaria $^{2}$, Mohammad Sadek Al Masalmeh ${ }^{2}$, Yaser Fawaz ${ }^{2}$, Abdoulraouf Allaham ${ }^{2}$, Imad Almani ${ }^{4}$, Hiba El- \\ Tarcheh $^{4}$, Ayham Ghazal ${ }^{3}$, Ali Zaher ${ }^{3}$, Hala Rifai ${ }^{5}$, Hamed Joumah $^{5}$, S. Dresden Glockler-Lauf ${ }^{6}$, Teresa To ${ }^{6,7}$ \\ ${ }^{1}$ National Center for Research on Chronic Respiratory Diseases, Tishreen University, Tishreen Hospital, Latakia, Syria; ${ }^{2}$ Department of Internal \\ Medicine, Syrian Private University, Damascus, Syria; ${ }^{3}$ Division of Psychiatry, ${ }^{4}$ Department of Internal Medicine, Damascus University, Damascus, \\ Syria; ${ }^{5}$ Internal Medicine, Ministry of Health, Hospital of Damascus, Damascus, Syria; ${ }^{6}$ Child Health Evaluative Sciences, the Hospital for Sick \\ Children, Toronto, Ontario, Canada; ${ }^{7}$ Dalla Lana School of Public Health, University of Toronto, Toronto, Ontario, Canada \\ Contributions: (I) Conception and design: Y Mohammad, T To; (II) Administrative support: Y Mohammad; (III) Provision of study materials or \\ patients: None; (IV) Collection and assembly of data: Y Mohammad, H Rifai, B Sawaf, MI Zakaria, MS Al Massalmeh, Y Fawaz, A Allaham, I \\ Almani, H El-Tarcheh, H Joumah, Y Latifeh, A Ghazal, A Zaher; (V) Data analysis and interpretation: S Rafea, T To; (VI) Manuscript writing: All \\ authors; (VII) Final approval of manuscript: All authors. \\ Correspondence to: Dr. Yousser Mohammad. Tishren University, Lattakia, Syria; Syrian Private University, Damascus, Syria. Email: ccollaborating@gmail.com.
}

Background: Studies have shown that poor shelter or dwelling conditions may lead to deteriorations in health. Those with asthma may be more susceptible to compromised living conditions and stress leading to a higher risk of asthma exacerbations. To describe the asthma control and quality of life of individuals with diagnosed asthma living in a shelter in Damascus, Syria and estimate the prevalence of respiratory symptoms in shelter dwellers without diagnosed asthma.

Methods: In this cross-sectional study, all individuals 5 years and older living in Al-Herjalleh shelter with diagnosed asthma were recruited to complete a questionnaire, which included items related to their respiratory symptoms, asthma exacerbations, exposure to asthma triggers, medication use, and health-related quality of life before and since entering the shelter. A representative sample of shelter dwellers without diagnosed asthma also completed a questionnaire to establish their demographics, respiratory symptoms, environment and chronic disease co-morbidities, in order to identify factors associated with under-diagnosed asthma. All participants underwent spirometry to measure their lung function. Descriptive statistics were calculated, and chi-square tests and Student's $t$-tests were used to compare individuals with asthma before and since entering the shelter, as well as to compare those with under-diagnosed asthma and individuals without asthma.

Results: The prevalence of asthma at the Al-Herjalleh shelter in those aged 5 years and older was approximately $8.5 \%$. Nearly $70 \%$ of the asthma group felt their asthma had worsened since entering the shelter, and there was a significant drop in the proportion of individuals using inhaled corticosteroids (ICS), with only $4.3 \%$ using daily ICS in the shelter $(\mathrm{P}<0.0001)$. The proportion of individuals experiencing a severe asthma attack did not change after entering the shelter $(\mathrm{P}=0.97)$, but almost all individuals with asthma (94.4\%) reported worsening in their health-related quality of life. In the non-asthma group, $44.2 \%$ of participants reported episodes of wheezing, coughing and breathlessness at night, consistent with underdiagnosed asthma. A higher proportion of those with under-diagnosed asthma had allergic rhinitis (57.1\%), symptoms of post-traumatic stress disorder (PTSD) (35.1\%), and abnormal spirometry (60.0\%), compared to those without asthma.

Conclusions: The findings of our study highlight the need for asthma programs in Syrian shelters as significant gaps exist in both the screening and management of chronic respiratory diseases to minimize asthma deterioration in Syrian shelter dwellers. 
Keywords: Underdiagnosed asthma; asthma in shelters; PTSD in asthma; war-time asthma

Submitted Jul 08, 2017. Accepted for publication Jul 11, 2017.

doi: $10.21037 /$ jtd.2017.08.86

View this article at: http://dx.doi.org/10.21037/jtd.2017.08.86

\section{Introduction}

According to the United Nations (UN), 6.5 million people have been internally displaced within Syria since the start of the civil war (1). As of 2016, 1.7 million internally displaced persons were living in camps and collective centres, including shelters (2). Studies have shown that poor shelter or dwelling conditions (such as overcrowding, lack of basic resources, and poor sanitation) may lead to deteriorations in health (3-6). For example, in the aftermath of the Great East Japan Earthquake and tsunami in 2011, the prevalence of asthma, exacerbations of chronic obstructive pulmonary disease (COPD), and community-acquired pneumonia were two to three times greater compared to the previous year, with half of the community-acquired pneumonia cases originating in evacuation shelters (6). Individuals with asthma may be more susceptible to compromised living conditions and stress leading to a higher risk of asthma exacerbations and other complications (3-6). It is important to identify uncontrolled asthmatics and those who are underdiagnosed or at-risk of developing asthma in order to target preventive strategies and asthma management to minimize the deterioration of asthma control.

The primary study objective was to describe the asthma control and quality of life of individuals with diagnosed asthma $(7,8)$ living in a shelter in Damascus, Syria. We described the living conditions in shelters and asthmarelated health outcomes. Specifically, we investigated frequency of respiratory symptoms, asthma exacerbations, exposure to new triggers associated with the ongoing war, exposure to second-hand smoke (SHS), crowding, access to medication and access to specialty care for those with severe asthma.

In addition, we had three secondary objectives: (I) to measure asthma-related symptoms among shelter dwellers who have not previously been diagnosed with asthma; (II) to estimate the prevalence of symptoms of post-traumatic stress disorder (PTSD) in the shelter dwellers; and (III) to screen for other chronic disease co-morbidities, including allergic rhinitis, hypertension, and diabetes.

\section{Methods}

\section{Study populations}

A total of 850 internally displaced persons settled in the AlHerjalleh shelter in Damascus, Syria. Two distinct groups were recruited to participate in this cross-sectional study: (I) prevalent and incident asthma group (those with existing asthma, and those newly diagnosed after coming to the shelter, respectively); and (II) non-asthma group (those without diagnosed asthma).

For the prevalent and incident asthma group, all individuals aged 5 years and older with self-reported diagnosed asthma were recruited to participate. The primary outcomes were asthma control and quality of life. Both outcomes were assessed by administering a questionnaire, which included asthma indicators that were recommended by the Canadian Primary Care guidelines $(7,8)$. Participants were asked to recall their symptoms and quality of life prior to entering the shelter, and report their current status as shelter dwellers. Additionally, data on asthma medication use and exposure to new asthma triggers were collected. With respect to environmental factors associated with respiratory health, information was collected on exposure to indoor air pollutants and crowding in the Al-Herjalleh shelter. Participants' lung function was measured by a trained researcher using a Spirobank portable spirometer, using American Thoracic Society (ATS)/European Respiratory Society (ERS) guidelines. To address our secondary objectives, participants were screened for symptoms of PTSD (including physical symptoms, traumatic flashbacks, and cognitive symptoms) as well as chronic disease co-morbidities (hypertension, allergic rhinitis, and diabetes).

For the non-asthma group, a representative sample of shelter dwellers aged 5 years and older were recruited to participate. A questionnaire was administered to all participants, which included items related to respiratory symptoms, smoking status, chronic disease co-morbidities, crowding, exposure to triggers of respiratory exacerbations, and symptoms of PTSD. A trained researcher measured the participants' lung function using a Spirobank spirometer. 
Individuals in the non-asthma group were further subdivided into those with under-diagnosed asthma and those who did not have asthma, based on whether they reported episodes of coughing, wheezing and breathlessness at night. Questionnaires used in this study can be found on the online supplement (Supplement I).

\section{Statistical analysis}

Descriptive statistics were calculated for both the prevalent and incident asthma group and non-asthma group. Continuous variables were described using medians, means and standard deviations. Categorical variables were described using frequency distributions and percentages. Student's $t$-tests and chi-square tests were used to assess the statistical significance of differences between those with under-diagnosed asthma and those who did not have asthma and to identify factors associated with under-diagnosed asthma. All analyses were completed using the Statistical Package for the Social Sciences (SPSS) version 18 (IBM Corporation, Armonk, NY, USA).

\section{Results}

\section{Prevalent and incident asthma group}

Among the 850 individuals living in the Al-Herjalleh shelter, 72 were previously diagnosed with asthma, either before or since entering the shelter. The prevalence of asthma at the Al-Herjalleh shelter in those aged 5 years and older was approximately $8.5 \%$. Descriptive statistics for the prevalent and incident asthma group are presented in Table 1. The age of participants ranged from 5 to 76 years, with a mean of 26.1 years (SD: 18.8). There was a slightly higher proportion of males $(52.8 \%)$ and the majority of adults with asthma $(91.7 \%)$ were married and living with their family. Only one third (34.7\%) of those with asthma were employed. The average monthly income in the prevalent and incident asthma group was $\$ 16.63$ (SD: 10.5), with $91.7 \%$ of the group earning less than $\$ 2$ per day.

More than half $(52.9 \%)$ of the individuals with asthma were diagnosed by a private pulmonologist, one third ( $34.3 \%$ ) by a general doctor, and $12.9 \%$ were diagnosed in a primary care centre. Nearly $70 \%$ of the asthma group felt their asthma had worsened since entering the shelter, with $57.1 \%$ of those on a short-acting beta2-agonist (SABA) inhaler reporting increased use. There was a significant drop in the proportion of individuals using inhaled corticosteroids (ICS) since entering the shelter, with only $4.3 \%$ using daily ICS in the shelter $(\mathrm{P}<0.0001)$. When asked how frequently they were awoken by their asthma, $59.2 \%$ said they woke up more since coming to the shelter. Even though the shelter dwellers had uncontrolled asthma, the proportion of individuals experiencing a severe asthma attack did not change after entering the shelter $(\mathrm{P}=0.97)$. Almost all individuals with asthma (94.4\%) reported worsening in their health-related quality of life since coming to the shelter. The mean percent predicted $\mathrm{FEV}_{1}$ $\left(\mathrm{FEV}_{1} \%\right)$ before bronchodilators for the asthma group was $87 \%$ (SD: $19 \%$ ), and the $\mathrm{FEV}_{1} \%$ for $30.0 \%$ of participants indicated an obstructive defect $(<80 \%)$. After administering a bronchodilator, $66.7 \%$ of those with an obstructive defect demonstrated total reversibility, while the spirometry of $33.3 \%$ was indicative of a fixed airway disease, with an abnormal $\mathrm{FEV}_{1} \%$ and an abnormal $\mathrm{FEV}_{1} / \mathrm{FVC}$ ratio (<70\%) after bronchodilators.

Table 2 shows changes in conditions before and after coming to the shelters. In terms of crowding, the number of persons living in the same room at the shelter was not significantly different from before entering the shelter $(\mathrm{P}=0.83)$. The most common new asthma trigger was odor from other shelter dwellers (36.1\%), including smells associated with cooking and/or heating. Other common asthma triggers were dust, SHS, detergents, and stress. A significantly higher proportion of individuals in the asthma group reported smoking cigarettes since entering the shelter $(51.4 \%, \mathrm{P}<0.05)$.

With regard to our secondary objectives, $26.7 \%$ of participants aged 30 years and older had hypertension. Of all those in the asthma group, $16.7 \%$ reported symptoms of PTSD. Two-thirds of the individuals with symptoms of PTSD had physical manifestations, half had traumatic flashbacks, and $41.7 \%$ had cognitive symptoms.

\section{Non-asthma group}

Table 3 shows the characteristics of 204 participants with either under-diagnosed asthma or without asthma. Of these shelter dwellers, 113 did not have asthma symptoms and 91 were not previously diagnosed with asthma, but reported episodes of wheezing, coughing and breathlessness at night, which indicate under-diagnosed asthma. Those with under-diagnosed asthma did not differ significantly from those with no asthma in terms of age, gender, diabetes, hypertension, smoking status or exposure to SHS. A significantly higher proportion of those with under- 
Table 1 Descriptive characteristics of participants with diagnosed asthma (n=72)

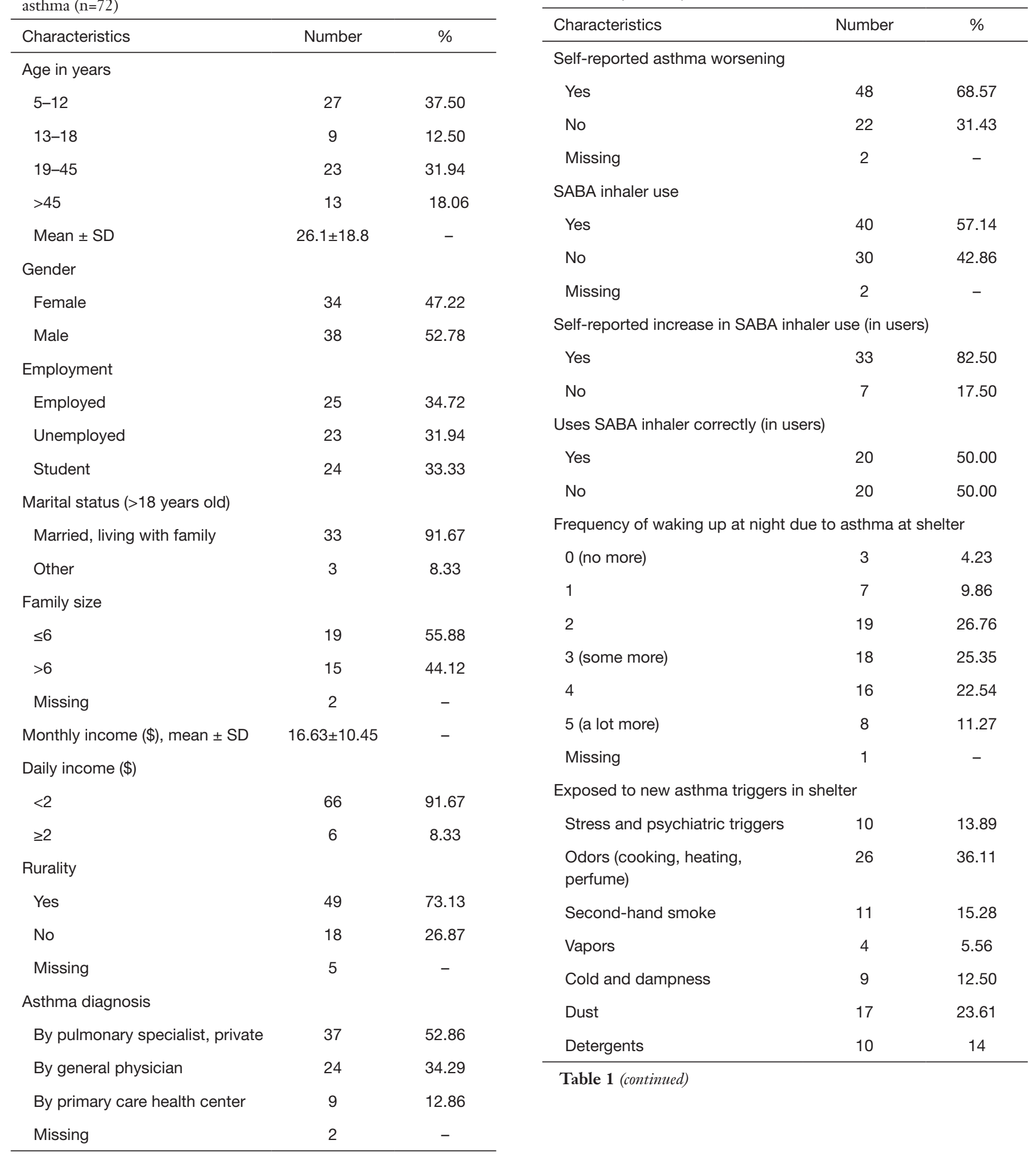

Table 1 (continued)
Table 1 (continued)

Frequency of waking up at night due to asthma at shelter

Table 1 (continued) 
Table 1 (continued)

\begin{tabular}{|c|c|c|}
\hline Characteristics & Number & $\%$ \\
\hline \multicolumn{3}{|c|}{ Self-reported worsening of quality of life } \\
\hline 0 & 4 & 5.63 \\
\hline 1 & 5 & 7.04 \\
\hline 2 & 25 & 35.21 \\
\hline 3 & 17 & 23.94 \\
\hline 4 & 16 & 22.54 \\
\hline 5 & 4 & 5.63 \\
\hline Missing & 1 & - \\
\hline \multicolumn{3}{|c|}{ Medical emergency point accessible $24 \mathrm{~h}$ prior to shelter } \\
\hline Yes & 42 & 59.15 \\
\hline No & 29 & 40.85 \\
\hline Missing & 1 & - \\
\hline \multicolumn{3}{|c|}{ Know someone who died from asthma attack at shelter } \\
\hline Yes & 6 & 9.38 \\
\hline No & 58 & 90.63 \\
\hline Missing & 8 & - \\
\hline \multicolumn{3}{|c|}{ Exposed to cigarette smoke in the shelter, non-smokers } \\
\hline Yes & 18 & 51.43 \\
\hline No & 17 & 48.57 \\
\hline \multicolumn{3}{|c|}{ Asthma triggered by cigarette smoke, non-smokers } \\
\hline Yes & 15 & 83.33 \\
\hline No & 3 & 16.67 \\
\hline $\begin{array}{l}\text { FEV } 1(\%) \text { before bronchodilators } \\
(n=70) \text {, mean } \pm S D\end{array}$ & $87 \pm 19$ & - \\
\hline \multicolumn{3}{|c|}{ FEV $1(\%)$ before bronchodilators $(n=70)$} \\
\hline$<80$ & 21 & 30.00 \\
\hline$\geq 80$ & 49 & 70.00 \\
\hline $\begin{array}{l}\text { FEV } 1(\%) \text { after bronchodilators } \\
(n=21) \text {, mean } \pm S D\end{array}$ & $87 \pm 19$ & - \\
\hline \multicolumn{3}{|c|}{$\mathrm{FEV}_{1}(\%)$ after bronchodilators $(\mathrm{n}=21)$} \\
\hline$<80$ & 7 & 33.33 \\
\hline$\geq 80$ & 14 & 66.67 \\
\hline \multicolumn{3}{|c|}{$\mathrm{FEV}_{1} / \mathrm{FVC}(\%)$ after bronchodilators $(\mathrm{n}=21)$} \\
\hline$<70$ & 7 & 33.33 \\
\hline$\geq 70$ & 14 & 66.67 \\
\hline
\end{tabular}

Table 1 (continued)
Table 1 (continued)

\begin{tabular}{|c|c|c|}
\hline Characteristics & Number & $\%$ \\
\hline \multicolumn{3}{|l|}{ Oxygen saturation $\left(\mathrm{SpO}_{2}\right)(\%)$} \\
\hline$<92$ & 5 & 7.14 \\
\hline$\geq 92$ & 65 & 92.86 \\
\hline Missing & 2 & - \\
\hline $\begin{array}{l}\text { Systolic blood pressure }(\mathrm{mmHg}) \\
(\mathrm{n}=29) \text {, mean } \pm \text { SD }\end{array}$ & $131 \pm 20$ & - \\
\hline $\begin{array}{l}\text { Diastolic blood pressure }(\mathrm{mmHg}) \\
(\mathrm{n}=29), \text { mean } \pm S D\end{array}$ & $83 \pm 14$ & - \\
\hline \multicolumn{3}{|l|}{ Hypertension (>30 years old) } \\
\hline Yes & 8 & 26.67 \\
\hline No & 22 & 73.33 \\
\hline \multicolumn{3}{|l|}{ Any symptom of PTSD } \\
\hline Yes & 12 & 16.67 \\
\hline No & 60 & 83.33 \\
\hline \multicolumn{3}{|l|}{ PTSD symptoms ( $n=12)$} \\
\hline Physical symptoms & 8 & 66.67 \\
\hline Flashbacks & 6 & 50.00 \\
\hline Cognitive symptoms & 5 & 41.67 \\
\hline
\end{tabular}

diagnosed asthma had allergic rhinitis compared to those with no asthma $(57.1 \%$ vs. $25.7 \%, \mathrm{P}<0.0001)$. Similarly, a higher proportion of those with under-diagnosed asthma reported symptoms of PTSD (35.1\% vs. $15.7 \%, \mathrm{P}<0.05)$, though their PTSD symptom profile was not significantly different from those with no asthma $(\mathrm{P}=0.70)$.

The mean $\mathrm{FEV}_{1} \%$ for the under-diagnosed asthma group (83\%, SD: $23 \%$ ) was lower than that of the no asthma group ( $89 \%$, SD: $17 \%$ ). More than $45.5 \%$ (40 persons) of those in the under-diagnosed asthma group had an $\mathrm{FEV}_{1} \%$ of less than $80 \%$, indicating an obstructive defect, compared to only $27 \%$ in the no asthma group. Four persons of 10 in the no asthma group who underwent reversibility test continued to have $\mathrm{FEV}_{1}<80 \%$, and $\mathrm{FEV}_{1} / \mathrm{FVC}<70 \%$ in 5 persons $(5 / 104=4.81 \%)$. One in 5 persons $(17 / 85=20 \%)$ in the under-diagnosed asthma group continued to have $\mathrm{FEV}_{1} / \mathrm{FVC}<70 \%$ after bronchodilators which is indicative of fixed airway disease (i.e., COPD, or asthma and COPD overlap). 
Table 2 Changes in asthma control before and after coming to the shelter in participants with diagnosed asthma $(\mathrm{n}=72)$

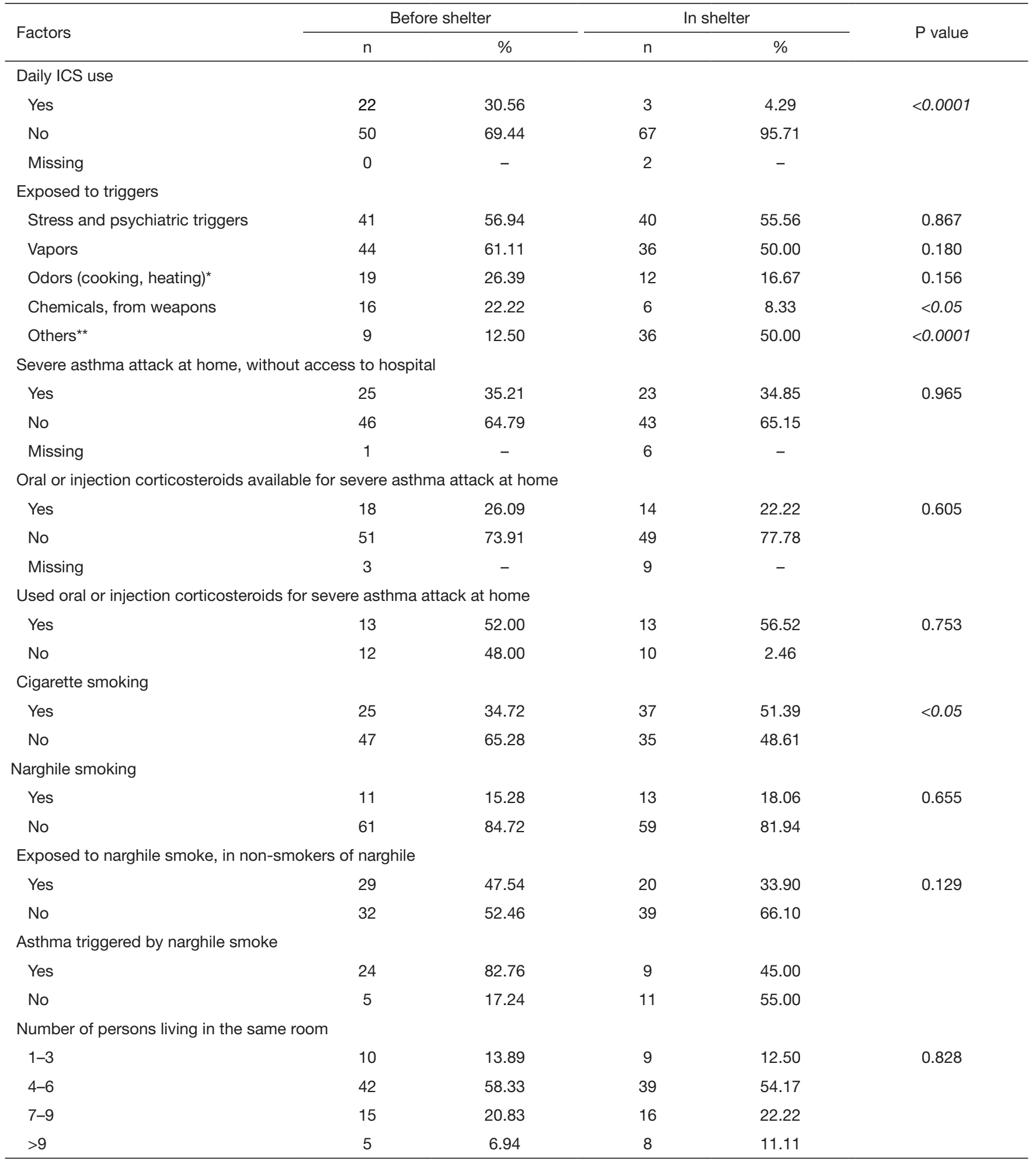

${ }^{*}$, heating or cooking using fuels such as plastic, trashes, cartoon, and wheels; ${ }^{*}$, odors of unburied victims in conflict zones before coming to shelter; $P$ values in italic form indicate statistical significance if $<0.05$. ICS, inhaled corticosteroids. 
Table 3 Characteristics of participants with under-diagnosed asthma $(\mathrm{n}=91)$ and those without asthma $(\mathrm{n}=113)$

\begin{tabular}{|c|c|c|c|}
\hline \multirow{2}{*}{ Characteristics } & $\begin{array}{l}\text { Under-diagnosed } \\
\text { asthma }(n=91)\end{array}$ & $\begin{array}{l}\text { No asthma } \\
(n=113)\end{array}$ & $P$ value \\
\hline & $\%$ & $\%$ & \\
\hline
\end{tabular}

\begin{tabular}{lcccc}
\hline Age in years & & & & \\
$5-12$ & 15 & 16.48 & 16 & 14.29 \\
$13-18$ & 12 & 13.19 & 12 & 10.71 \\
$19-45$ & 33 & 36.26 & 43 & 38.39 \\
$45-65$ & 21 & 23.08 & 38 & 33.93 \\
$>65$ & 10 & 10.99 & 3 & 2.68 \\
Missing & 0 & - & 1 & -
\end{tabular}

Gender

$\begin{array}{llllll}\text { Female } & 55 & 60.44 & 73 & 64.60 & 0.541 \\ \text { Male } & 36 & 39.56 & 40 & 35.40 & \end{array}$

Any chronic disease

$\begin{array}{lllll}\text { Yes } & 40 & 43.96 & 52 & 46.02 \\ \text { No } & 51 & 56.04 & 61 & 53.98\end{array}$

Diabetes

$\begin{array}{lrrrrr}\text { Yes } & 6 & 6.59 & 14 & 12.39 & 0.166 \\ \text { No } & 85 & 93.41 & 99 & 87.61 & \end{array}$

Hypertension

$\begin{array}{llllll}\text { Yes } & 14 & 15.38 & 17 & 15.04 & 0.946 \\ \text { No } & 77 & 84.62 & 96 & 84.96 & \end{array}$

Chronic disease since entering shelter

$\begin{array}{lccccc}\text { Yes } & 16 & 42.11 & 17 & 37.78 & 0.688 \\ \text { No } & 22 & 57.89 & 28 & 62.22 & \\ \text { Missing } & 2 & - & 7 & - & \end{array}$

Cigarette smoker, before entering shelter

$\begin{array}{llllll}\text { Yes } & 19 & 20.88 & 34 & 30.09 & 0.136 \\ \text { No } & 72 & 79.12 & 79 & 69.91 & \end{array}$

Cigarette smoker, since entering shelter

$\begin{array}{cccccc}\text { Yes } & 4 & 5.56 & 5 & 4.42 & 0.841 \\ \text { No } & 68 & 94.44 & 74 & 93.67 & \end{array}$

Non-smokers exposed to second-hand cigarette smoke, before entering shelter

\begin{tabular}{llllll} 
Yes & 43 & 59.72 & 57 & 72.15 & 0.107 \\
No & 29 & 40.28 & 22 & 27.85 & \\
\hline
\end{tabular}

Table 3 (continued)
Table 3 (continued)

\begin{tabular}{|c|c|c|c|}
\hline \multirow{2}{*}{ Characteristics } & $\begin{array}{c}\text { Under-diagnosed } \\
\text { asthma }(n=91)\end{array}$ & $\begin{array}{l}\text { No asthma } \\
(n=113)\end{array}$ & $P$ value \\
\hline & $\%$ & $\%$ & \\
\hline
\end{tabular}

Non-smokers exposed to second-hand cigarette smoke, since entering shelter

$\begin{array}{llllll}\text { No } & 23 & 33.82 & 19 & 25.68 & 0.288 \\ \text { Yes } & 45 & 66.18 & 55 & 74.32 & \end{array}$

Narghile smoker, before entering shelter

$\begin{array}{lrrrrr}\text { Yes } & 7 & 7.69 & 10 & 8.85 & 0.766 \\ \text { No } & 84 & 92.31 & 103 & 91.15 & \end{array}$

Narghile smoker, since entering shelter

$\begin{array}{cccccc}\text { Yes } & 4 & 4.76 & 2 & 1.94 & 0.276 \\ \text { No } & 80 & 95.24 & 101 & 98.06 & \end{array}$

Exposed to second-hand narghile smoke, before entering shelter

$\begin{array}{llllll}\text { Yes } & 28 & 33.33 & 29 & 28.16 & 0.444 \\ \text { No } & 56 & 66.67 & 74 & 71.84 & \end{array}$

Exposed to second-hand narghile smoke, since entering shelter

$\begin{array}{llllll}\text { Yes } & 26 & 32.50 & 31 & 30.1 & 0.728 \\ \text { No } & 54 & 67.50 & 72 & 69.9 & \end{array}$

Allergic rhinitis

$\begin{array}{llllll}\text { Yes } & 52 & 57.14 & 29 & 25.66 & <0.0001 \\ \text { No } & 39 & 42.86 & 84 & 74.34 & \end{array}$

$\mathrm{FEV}_{1}(\%)$ before bronchodilators

$\begin{array}{llllll}\text { Mean } \pm S D & 83 \pm 23 \quad & - & 89 \pm 17 \quad & - & 0.013\end{array}$

FEV 1 (\%) before bronchodilators $(n=195)$
$<80$
$40 \quad 45.45$
$29 \quad 27.10$
0.008

$\mathrm{FEV}_{1}(\%)$ after bronchodilators $(\mathrm{n} 1=27, \mathrm{n} 2=10)$

$\begin{array}{llllll}\text { Mean } \pm \text { SD } \quad 76 \pm 25 \quad & - & 84 \pm 21 \quad & - & 0.403\end{array}$

$\mathrm{FEV}_{1}(\%)$ after bronchodilators

$\begin{array}{llllll}<80 & 15 / 27 & 55.56 & 4 / 10 & 40.00 & 0.401\end{array}$

FEV $1 / F V C(\%)$ after bronchodilators

$$
\begin{array}{llllll}
<70 & 17 / 85 & 20.00 & 5 / 104 & 4.81 & 0.001
\end{array}
$$

Oxygen saturation $\left(\mathrm{SpO}_{2}\right)(\%)$

$$
\text { Mean } \pm \text { SD } \quad 97 \pm 2 \quad-\quad 97 \pm 2 \quad-
$$

Systolic blood pressure $(\mathrm{mmHg})$ (in $>30$ years)

\begin{tabular}{lllll} 
Mean \pm SD $\quad 130 \pm 32 \quad-\quad 130 \pm 31 \quad-$ \\
\hline
\end{tabular}

Table 3 (continued) 
Table 3 (continued)

\begin{tabular}{lcccc}
\hline Characteristics & $\begin{array}{c}\text { Under-diagnosed } \\
\text { asthma }(n=91)\end{array}$ & & $\begin{array}{c}\text { No asthma } \\
(n=113)\end{array}$ & P value \\
\cline { 2 - 3 } & $n$ & $\%$ & &
\end{tabular}

Systolic blood pressure $(\mathrm{mmHg})$ (in $>30$ years)

$\begin{array}{lllll}>140 & 16 / 57 & 28.07 & 19 / 71 & 26.76\end{array}$

Diastolic blood pressure $(\mathrm{mmHg})$

Mean \pm SD $85 \pm 20 \quad$ - $82 \pm 18$ -

Any symptom of PTSD

$\begin{array}{lccccc}\text { Yes } & 20 & 35.09 & 11 & 15.71 & <0.05 \\ \text { No } & 37 & 64.91 & 59 & 84.29 & \\ \text { Missing } & 34 & - & 43 & - & \end{array}$

Symptoms of PTSD

$\begin{array}{lccccc}\begin{array}{l}\text { Physical } \\ \text { symptoms }\end{array} & 11 & 55.00 & 4 & 36.36 & 0.696 \\ \begin{array}{l}\text { Flashbacks } \\ \begin{array}{l}\text { Cognitive } \\ \text { symptoms }\end{array}\end{array} & 3 & 15.00 & 3 & 27.27 & \\ \begin{array}{l}\text { Multiple } \\ \text { symptoms }\end{array} & 2 & 10.00 & 2 & 18.18\end{array}$

$P$ values in italic form indicate statistical significance if $P<0.05$.

\section{Discussion}

In our study, which included both children and adults settled in the Al-Herjalleh shelter, we estimated the prevalence of asthma to be $8.5 \%$, which is consistent with the average of estimates from the International Study of Asthma and Allergies in Childhood (ISAAC) and the WHO-Global Alliance against Chronic Respiratory Disease (WHOGARD). ISAAC estimated that the prevalence of asthma (defined as wheezing in the last 12 months without having a cold in children aged 13-14 years) was $5.2 \%$ in Syria (9), and according to a primary care survey implemented in collaboration with the WHO-GARD, the prevalence of asthma in Syrian individuals presenting to a primary care center for any reason was estimated to be $13 \%$ (10). The average of these two asthma prevalence estimates, $9.1 \%$, is very close to what we observed in the Al-Herjalleh shelter.

Individuals with previously diagnosed asthma at the AlHerjalleh shelter had poorly controlled and worsening asthma, which impacted their quality of life. Daily ICS use was low, declining from $30.1 \%$ before entering the shelter to $4.3 \%$ in the shelter, and only half of those using an inhaler demonstrated the correct technique. The war and subsequent displacement have led those with asthma to be exposed to several new triggers, including odors, stress, SHS, and chemicals. A number of individuals with asthma have also taken up smoking cigarettes or narghile since entering the shelter. Surprisingly, the proportion of individuals experiencing severe asthma attacks did not change significantly after entering the shelter, nor did their access to emergency department. However, nearly half of them took oral corticosteroids as rescue medication. Nighttime symptoms are considered the most sensitive and specific for asthma diagnosis in validated epidemiological studies such as the ECRHS (11). In the non-asthma group, a shocking $44.2 \%$ of participants reported episodes of wheezing, coughing and breathlessness at night, consistent with under-diagnosed asthma. A high proportion of those subdivided into the under-diagnosed asthma group (35.1\%) reported symptoms of PTSD, which may account for their shortness of breath or coughing at night (paroxysmal nocturnal dyspnea, wheeze and cough). It is plausible because individuals with PTSD exhibit an altered phenotype of regulatory T cells (12) and furthermore, it has been suggested that asthma onset can be linked to family/personal disasters (13) which is the case in these shelter dwellers (loss of home and/or family member). There are also other adverse factors in shelter living. For example, cooking in the same room where the family lives may increase the exposure to particulate matters $\left(\mathrm{PM}_{2.5}\right)$ which can exacerbate asthma (14). Other triggers include use of detergent such as bleach (sodium hypochlorite), which is widely used in Syria (15) and amongst the shelter dwellers, exposure to SHS $(16,17)$ and poverty $(17,18)$ (the study participants had an average daily income of less than 2 USD/day). Finally, our spirometry data also suggested that both asthma and COPD were severely under-diagnosed, and thus not adequately managed.

The findings of our study highlight the need for asthma programs in Syrian shelters, as significant gaps exist in both the screening and management of chronic respiratory diseases. Although a primary care centre was nearby, and those in the Al-Herjalleh shelter had access to an emergency department during the conflict, however, screening and management campaigns were not integrated into the shelters. Fortunately, since our survey was conducted, collaborators from the Non-Communicable Disease (NCD) Department at the Syrian Ministry of Health (MOH) and the WHO country office agreed to include shelters in the 
national chronic respiratory disease program. Already, the MOH has distributed ICS to shelter dwellers with asthma, and provided training for primary care doctors and nurses in chronic respiratory disease. The $\mathrm{MOH}$ is also collaborating with Tishreen University and WHO Country office to publish national guidelines on evidence-based diagnosis and management of chronic respiratory disease. With continued funding, support and evaluation, we hope these programs will minimize asthma deterioration in Syrian shelter dwellers.

\section{Conclusions}

Amongst shelter dweller in Syria, asthma is uncontrolled and poorly managed and underdiagnosed asthma is prevalent. More than 2 of 5 of those indicated without asthma had night attacks of wheeze, cough and breathlessness consistent with asthma with the majority of them confirmed of asthma with lung function measures. Fixed airflow limitation after bronchodilators allude to underdiagnosed COPD, very severe uncontrolled asthma, or asthma-COPD overlap $(19,20)$. As result to our survey and findings, shelters have been included in the national program of Chronic Respiratory Disease (CRD) launched in collaboration amongst the $\mathrm{MOH}$, the Ministry of Higher Education and the WHO country office.

\section{Acknowledgements}

We thank the Syrian Private University Council for sponsoring the survey. Special thanks to: Drs. Fatmeh Hassan and Bashar Kaddour of the Department of Rural Health in Damascus for their administrative and implementation assistance in the field work; Drs. Rania Shifa and Ahmad Dmeirieh of the Directorate of NCD in $\mathrm{MOH}$ for initiating the National Committee for Chronic Respiratory Disease in collaboration with WHO and the Ministry of Higher Education; and Drs. Elizabeth Hoff, Aicha Al-jaber and Ghada Muhjazi of the WHO country office for reviewing the manuscript prior to submission. Last but not least, we acknowledge the Global Alliance Against Chronic Respiratory Disease (GARD www. who.int/gard) for the opportunity to collaborate with the Ontario Asthma Surveillance Information System (OASIS) in Toronto, Canada. The study was funded by a grant from the Syrian Private University. Damascus Hospital and Tishreen University gave Spirometric equipment.

\section{Footnote}

Conflicts of Interest: The authors have no conflicts of interest to declare.

Ethical statement: Ethical approval was obtained according to our university rules. Written informed consent was obtained from the patient for publication of this manuscript and any accompanying images.

\section{References}

1. The United Nations Refugee Agency (Syria). Internally Displaced People. Accessed June 28 2017. Available online: http://www.unhcr.org/sy/29-internally-displaced-people. html

2. Syria Emergency Shelter Sector. Syria Emergency Shelter Sector Factsheet, 2016 August. Accessed June 282017. Available online: http://www.unhcr.org/sy/wp-content/ uploads/sites/3/2016/11/Shelter-Sector-August.pdf

3. Kolwaite AR, Hlady WG, Simon MC, et al. Assessing functional needs sheltering in Pike County, Kentucky: using a community assessment for public health emergency response. Disaster Med Public Health Prep 2013;7:597602.

4. Szema AM, Peters MC, Weissinger KM, et al. New-onset asthma among soldiers serving in Iraq and Afghanistan. Allergy Asthma Proc 2010;31:67-71.

5. Cutuli JJ, Herbers JE, Rinaldi M, et al. Asthma and behavior in homeless 4- to 7-year-olds. Pediatrics 2010;125:145-51.

6. Ohkouchi S, Shibuya R, Yanai M, et al. Deterioration in regional health status after the acute phase of a great disaster: respiratory physicians' experiences of the Great East Japan Earthquake. Respir Investig 2013;51:50-5.

7. To T, Guttmann A, Lougheed MD, et al. Evidence-based performance indicators of primary care for asthma: a modified RAND Appropriateness Method. International Journal for Quality in Health Care 2010;22:476-85.

8. To T, McLimont S, Daly C, et al. Is it feasible to use indicators to collect data on asthma care performance in the primary care setting? A feasibility study. Prim Care Respir J 2011;20:452-3.

9. Mohammad Y, Tabbah K, Mohammad S, et al. International study of asthma and allergies in childhood: phase 3 in the Syrian Arab Republic. East Mediterr Health J 2010;16:710-6.

10. Mohammad Y, Shaaban R, Yassine F, et al. Executive 
summary of the multicenter survey on the prevalence and risk factors of chronic respiratory diseases in patients presenting to primary care centers and emergency rooms in Syria. J Thorac Dis 2012;4:203-5.

11. Burney PG, Luczynska C, Chinn S, et al. The European Community Respiratory Health Survey. Eur Respir J 1994;7:954-60.

12. Jergovic M, Bendelja K, Vidovic A, et al. Patients with posttraumatic stress disorder exhibit an altered phenotype of regulatory T cells. Allergy Asthma Clin Immunol 2014;10:43.

13. Halimi L, Vachier I, Varrin M, et al. Interference of psychological factors in difficult-to-control asthma. Respir Med 2007;101:154-61.

14. Phillips MJ, Smith EA, Mosquin PL, et al. Sri Lanka Pilot Study to Examine Respiratory Health Effects and Personal PM2.5 Exposures from Cooking Indoors. Int J Environ Res Public Health 2016;13.

15. Quirce S, Barranco P. Cleaning agents and asthma. J

Cite this article as: Mohammad Y, Rafea S, Latifeh Y, Khaddam A, Sawaf B, Zakaria MI, Al Masalmeh MS, Fawaz Y, Allaham A, Almani I, El-Tarcheh H, Ghazal A, Zaher A, Rifai H, Joumah H, Glockler-Lauf SD, To T. Uncontrolled and under-diagnosed asthma in a Damascus shelter during the Syrian crisis. J Thorac Dis 2017;9(9):3415-3424. doi: 10.21037/ jtd.2017.08.86
Investig Allergol Clin Immunol 2010;20:542-50; quiz 2p following 550 .

16. Mohammad Y. Passive smoking interference with wheezing and asthma: short review of current knowledge. Pulmonology and Respiratory Research 2015;3:1.

17. Zar HJ, Ferkol TW. The global burden of respiratory disease-impact on child health. Pediatr Pulmonol 2014;49:430-4.

18. Fattore GL, Santos CA, Barreto ML. Social determinants of childhood asthma symptoms: an ecological study in urban Latin America. J Community Health 2014;39:355-62.

19. Global Initiative for Asthma (GINA). Global strategy for asthma management and prevention. 2017. Accessed June 28 2017. Available online: http://www.ginasthma.org

20. (GOLD) TGIfCOLD. Global initiative for chronic obstructive lung diseases 2017. Accessed June 282017. Available online: http://www.goldcopd.org 


\section{Supplement I Online supplement: study questionnaires}

\section{Online Supplement: Study Questionnaires}

\section{Prevalent and Incident Asthma Group}

Patient Demographics

1. Age (years):

2. Height $(\mathrm{cm})$ :

3. Weight $(\mathrm{kg})$ :

4. Sex: $(\mathrm{M} / \mathrm{F})$

5. Number of individuals in your immediate family:

6. Occupation/Occupation of head of family:

7. Education/Education of head of family:

8. How long have you been in the shelter?

9. Previous residence: (Urban/Rural)

\section{Asthma History}

10. Were you diagnosed with asthma before entering the shelter? (Y/N) If $N$, continue to 11 . If $Y$, proceed to 12.

11. Were you diagnosed with asthma after entering the shelter? $(\mathrm{Y} / \mathrm{N})$

12. When were you diagnosed with asthma? (Year and age)

13. Who diagnosed your asthma? (Private Doctor/Hospital Outpatient Clinic/Primary Care Provider/Pharmacist/Family/Teacher/Colleague/Other)

14. Do you feel your asthma is getting worse (uncontrolled asthma)? (Y/N)

15. Did you use inhaled beta-2 agonists before coming to the shelter? (Y/N) If $Y$, continue to 15a. If $N$, proceed to 16.

a. Do you use inhaled beta-2 agonists more than before entering the shelter? (Y/N)

b. [Ask participants to show you how he/she uses the inhaler]. Did the participant use his/her inhaler correctly? (Y/N)

16. Have you been using inhaled beta-2 agonists since entering the shelter? (Y/N) If $Y$, continue to 16 . If $N$, proceed to 17.

a. How many times per day?

b. How many times at night? 
c. How many times per week?

17. On a scale of 0 to 5 , do you wake up more at night since coming to the shelter? (Circle your answer)

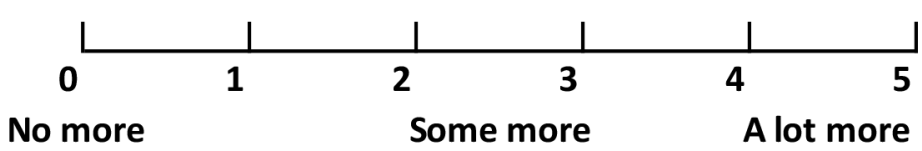

18. Did you use inhaled corticosteroids (ICS) before coming to the shelter? (Y/N) If $Y$, proceed to 18 a. If $N$, continue to 19.

a. Specify brand of ICS:

b. Dose:

c. Did you take ICS daily as prescribed? (Y/N) If $N$, continue to $18 d$. If $Y$, proceed to 19.

d. How many days did you take ICS per week? (0-7)

19. Have you been using ICS since entering the shelter? If $Y$, proceed to $19 a$. If $N$, continue to 20 .

a. Specify brand of ICS:

b. Dose:

20. Were you exposed to the following triggers, before entering the shelter:
a. Vapours $(\mathrm{Y} / \mathrm{N})$
b. Chemicals $(\mathrm{Y} / \mathrm{N})$
c. Stress $(\mathrm{Y} / \mathrm{N})$
d. Secondhand smoke $(\mathrm{Y} / \mathrm{N})$
e. Weapons $(\mathrm{Y} / \mathrm{N})$
f. $\operatorname{Odours}(\mathrm{Y} / \mathrm{N})$
g. Other (specify):

21. Have you been exposed to the following triggers, since entering the shelter:
a. Vapours $(\mathrm{Y} / \mathrm{N})$
b. Chemicals $(\mathrm{Y} / \mathrm{N})$
c. Stress $(\mathrm{Y} / \mathrm{N})$
d. Secondhand smoke $(\mathrm{Y} / \mathrm{N})$ 
e. Weapons $(\mathrm{Y} / \mathrm{N})$

f. $\operatorname{Odours}(\mathrm{Y} / \mathrm{N})$

g. Other (specify):

22. On a scale of 0 to 5 , how much did your asthma prevent you from living normally before entering the shelter? (Circle)

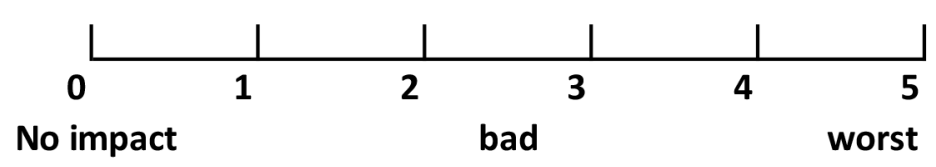

23. On a scale of 0 to 5 , how much is your asthma preventing you from living normally since entering the shelter? (Circle)

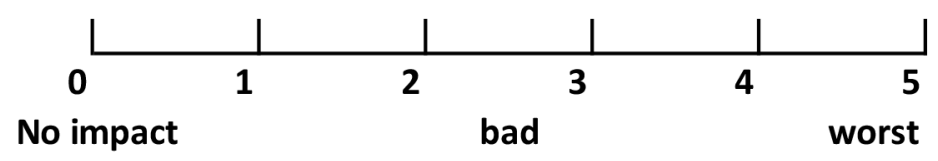

24. Before the war, were your medications free? $(\mathrm{Y} / \mathrm{N})$ If $Y$, continue to $24 a$. If $N$, proceed to 25.
a. Name of the medication:
b. Dose:

25. Are your medications now free? $(\mathrm{Y} / \mathrm{N})$ If $Y$, continue to $25 a$. If $N$, proceed to 26.
a. Name of the medication:
b. Dose:

26. Did you have a severe asthma attack before entering the shelter? (Y/N) If $Y$, continue to 26a. If $N$, proceed to 27.
a. Did you go to the ER?
b. Time to get to an ER at night: (hours, minutes)

27. Have you had a severe asthma attack since entering the shelter? (Y/N) If $Y$, continue to 27a. If $N$, proceed to 28.
a. Did you go to the ER?
b. Time to get to an ER at night: (hours, minutes) 
28. Did you have oral or injection corticosteroids available for an emergency (severe asthma attack) at home, before entering the shelter? (Y/N) If $Y$, continue to 28a. If $N$, continue to 29.

a. Did you use oral or injection corticosteroids for a severe asthma attack at home, before entering the shelter? $(\mathrm{Y} / \mathrm{N})$

29. Have you had oral or injection corticosteroids available for an emergency (severe asthma attack) at home, since entering the shelter? (Y/N) If $Y$, continue to 29a. If $N$, continue to 30.

a. Have you used oral or injection corticosteroids for a severe asthma attack at home, since entering the shelter? $(\mathrm{Y} / \mathrm{N})$

30. Before entering the shelter, did you have a severe asthma attack without access to a hospital? (Y/N)

31. Since entering the shelter, have you had a severe asthma attack without access to a hospital? (Y/N)

\section{Medical and Smoking History}

32. Do you have any other medical conditions? (Y/N) If $Y$, continue to $32 a$. If $N$, proceed to 33.

a. Hypertension: ( $\mathrm{Y} / \mathrm{N})$ If $Y$, continue to $32 b$. If $N$, proceed to $32 c$.

b. Did you develop hypertension while you were living in the shelter? $(\mathrm{Y} / \mathrm{N})$

c. Diabetes: $(\mathrm{Y} / \mathrm{N})$ If $Y$, continue to $32 d$. If $N$, proceed to 33 .

d. Did you develop diabetes while you were living in the shelter? $(\mathrm{Y} / \mathrm{N})$

33. Blood pressure, $\mathrm{mmHg}$ (systolic/diastolic):

34. Oxygen saturation, $\%\left(\mathrm{SpO}_{2}\right)$ :

35. Allergic rhinitis $(\mathrm{Y} / \mathrm{N})$ ?

36. Are you experiencing any symptoms of PTSD? (Y/N) If $Y$, continue to $36 a$. If $N$, END.
a. Physical symptoms (Y/N)
b. Traumatic flashbacks $(\mathrm{Y} / \mathrm{N})$
c. Cognitive symptoms $(\mathrm{Y} / \mathrm{N})$

37. List all your current medications: 
38. Are you now, or have you ever been a smoker? $(\mathrm{Y} / \mathrm{N})$ If $Y$, continue to 39. If $N$, proceed to 43 .

39. Were you a cigarette smoker before entering the shelter? (Y/N) If $N$, continue to 40 . If $Y$, proceed to 41.

40. Have you started smoking cigarettes since entering the shelter? $(\mathrm{Y} / \mathrm{N})$

41. Were you a narghile smoker before entering the shelter? ( $\mathrm{Y} / \mathrm{N}$ ) If $N$, continue to 42. If $Y$, proceed to 43.

42. Have you started smoking narghile since entering the shelter? (Y/N)

43. FOR NON-SMOKERS, BEFORE ENTERING THE SHELTER:

a. Were you exposed to secondhand cigarette smoke? $(\mathrm{Y} / \mathrm{N})$

b. Were you exposed to secondhand narghile smoke? (Y/N)

44. FOR NON-SMOKERS, SINCE ENTERING THE SHELTER:

a. Are you exposed to secondhand cigarette smoke? (Y/N)

b. Are you exposed to secondhand narghile smoke? $(\mathrm{Y} / \mathrm{N})$

\section{Environment}

45. How many people did you share a room with before entering the shelter?

46. How many people do you share a room with since entering the shelter?

\section{Lung Function}

47. FEV1\% and FEV1/FVC before bronchodilators. If $<80 \%$, continue to 48 . If $>80 \%$, proceed to 49.

48. FEV $1 \%$ and FEV1/FVC after bronchodilators.

49. Before the shelter, did you ever have a runny or blocked nose and sneezing when you did not have a cold?

50. Since entering the shelter, have you had a runny or blocked nose and sneezing when you did not have a cold? 


\section{Non-Asthma Group}

1. Age (years):

2. Sex: $(\mathrm{M} / \mathrm{F})$

3. Do you have a chronic disease? (Y/N) If $Y$, continue to $3 a$. If $N$, proceed to 6.
a. Diabetes $(\mathrm{Y} / \mathrm{N})$
b. Hypertension $(\mathrm{Y} / \mathrm{N})$
c. Other $(\mathrm{Y} / \mathrm{N})$

4. Was your chronic disease diagnosed before entering the shelter? $(\mathrm{Y} / \mathrm{N})$ If $N$, continue to 5. If $Y$, proceed to 6 .

5. Was your chronic disease diagnosed since entering the shelter? $(\mathrm{Y} / \mathrm{N})$

6. Were you a cigarette smoker before entering the shelter? $(\mathrm{Y} / \mathrm{N})$ If $N$, continue to 7 . If $Y$, proceed to 8 .

7. Have you started smoking cigarettes since entering the shelter? $(\mathrm{Y} / \mathrm{N})$

8. Were you a narghile smoker before entering the shelter? $(\mathrm{Y} / \mathrm{N})$ If $N$, continue to 9. If $Y$, proceed to 10 .

9. Have you started smoking narghile since entering the shelter? $(\mathrm{Y} / \mathrm{N})$

10. How many people did you share a room with before entering the shelter?

11. Were you exposed to second-hand smoke (cigarettes) before entering to shelter? $(\mathrm{Y} / \mathrm{N})$

12. Were you exposed to second-hand smoke (cigarettes) after entering to shelter? $(\mathrm{Y} / \mathrm{N})$

13. Were you exposed to second-hand smoke (narghile) before entering to shelter? (Y/N)

14. Were you exposed to second-hand smoke (narghile) after entering to shelter? (Y/N)

15. How many people do you share a room with after entering the shelter?

16. Do you experience nighttime episodes of cough, wheezing and breathlessness? (Y/N) If $Y$, continue to 16 . If $N$, proceed to 17.
a. Frequency: (weekly/monthly/yearly)
b. Triggers:

17. FEV1\% before bronchodilator If less than $80 \%$, continue to 17 a. If more than $80 \%$, proceed to 18 .

a. FEV1\% after broncodilator (reversibility test):

b. FEV1/FVC $<70 \%$ after bronchodilator (obstruction): 
18. Were you diagnosed with any chronic respiratory disease before entering the shelter? $(\mathrm{Y} / \mathrm{N})$

19. Blood pressure, $\mathrm{mmHg}$ (systolic/diastolic):

20. Oxygen saturation, $\%\left(\mathrm{SpO}_{2}\right)$ :

21. Allergic rhinitis $(\mathrm{Y} / \mathrm{N})$ ?

22. Are you experiencing any symptoms of PTSD? (Y/N) If $Y$, continue to 22a. If N, END.
a. Physical symptoms $(\mathrm{Y} / \mathrm{N})$
b. Traumatic flashbacks $(\mathrm{Y} / \mathrm{N})$
c. Cognitive symptoms $(\mathrm{Y} / \mathrm{N})$ 